\title{
Simulating the oxygen content of ambient organic aerosol with the 2D volatility basis set
}

\author{
B. N. Murphy ${ }^{1}$, N. M. Donahue ${ }^{1}$, C. Fountoukis ${ }^{2}$, and S. N. Pandis ${ }^{1,3}$ \\ ${ }^{1}$ Department of Chemical Engineering, Carnegie Mellon University 5000 Forbes Ave, Pittsburgh, Pennsylvania 15213, USA \\ ${ }^{2}$ Institute of Chemical Engineering and High Temperature Chemical Processes (ICE-HT), Foundation of Research and \\ Technology (FORTH), Patra, Greece \\ ${ }^{3}$ Department of Chemical Engineering, University of Patras, Patra, Greece
}

Received: 19 January 2011 - Published in Atmos. Chem. Phys. Discuss.: 11 March 2011

Revised: 12 July 2011 - Accepted: 19 July 2011 - Published: 4 August 2011

\begin{abstract}
A module predicting the oxidation state of organic aerosol (OA) has been developed using the two-dimensional volatility basis set (2D-VBS) framework. This model is an extension of the 1D-VBS framework and tracks saturation concentration and oxygen content of organic species during their atmospheric lifetime. The host model, a onedimensional Lagrangian transport model, is used to simulate air parcels arriving at Finokalia, Greece during the Finokalia Aerosol Measurement Experiment in May 2008 (FAME-08). Extensive observations were collected during this campaign using an aerosol mass spectrometer (AMS) and a thermodenuder to determine the chemical composition and volatility, respectively, of the ambient OA. Although there are several uncertain model parameters, the consistently high oxygen content of OA measured during FAME-08 $(\mathrm{O}: \mathrm{C}=0.8)$ can help constrain these parameters and elucidate OA formation and aging processes that are necessary for achieving the high degree of oxygenation observed. The base-case model reproduces observed OA mass concentrations (measured mean $=3.1 \mu \mathrm{g} \mathrm{m}^{-3}$, predicted mean $=3.3 \mu \mathrm{g} \mathrm{m}^{-3}$ ) and $\mathrm{O}: \mathrm{C}$ (predicted $\mathrm{O}: \mathrm{C}=0.78$ ) accurately. A suite of sensitivity studies explore uncertainties due to (1) the anthropogenic secondary OA (SOA) aging rate constant, (2) assumed enthalpies of vaporization, (3) the volatility change and number of oxygen atoms added for each generation of aging, (4) heterogeneous chemistry, (5) the oxidation state of the first generation of compounds formed from SOA precursor oxidation, and (6) biogenic SOA aging. Perturbations in most of these parameters do impact the ability of the model to predict O:C well throughout the simulation period. By comparing measurements of the O:C from FAME-08, several sensitivity cases including a high oxygenation case, a low oxy-
\end{abstract}

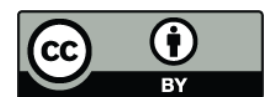

Correspondence to: S. N. Pandis (spyros@andrew.cmu.edu) genation case, and biogenic SOA aging case are found to unreasonably depict OA aging, keeping in mind that this study does not consider possibly important processes like fragmentation that may offset mass gains and affect the prediction bias. On the other hand, many of the cases chosen for this study predict average O:C estimates that are consistent with the observations, illustrating the need for more thorough experimental characterizations of OA parameters including the enthalpy of vaporization and oxidation state of the first generation of SOA products. The ability of the model to predict OA concentrations is less sensitive to perturbations in the model parameters than its ability to predict O:C. In this sense, quantifying $\mathrm{O}: \mathrm{C}$ with a predictive model and constraining it with AMS measurements can reduce uncertainty in our understanding of OA formation and aging.

\section{Introduction}

Organic aerosol (OA), although a significant component of submicron particles throughout the world, is poorly simulated by predictive models when compared to particulate inorganic constituents (Kanakidou et al., 2005; Fuzzi et al., 2006). Thousands of individual organic compounds make up this OA mixture, making its bulk properties (e.g. reactivity, volatility, hygroscopicity, etc.) difficult to assess and represent in mathematical models of the atmosphere (Goldstein and Galbally, 2007). These chemical transport models (CTMs) thus typically use surrogate species with averaged properties to represent dominant OA formation, evolution, and removal pathways in order to predict ambient OA mass concentrations at the Earth's surface or aloft. This OA mass concentration is believed currently to be the best predictor for negative human health impacts, and is therefore the preferred metric for government particulate matter regulation. Still,

Published by Copernicus Publications on behalf of the European Geosciences Union. 
current CTMs consistently underpredict OA mass concentrations, missing up to $80 \%$ of the observed material at the surface during summertime conditions (Morris et al., 2006). Underpredictions at high altitudes have been reported as well (Heald et al., 2005).

The distribution of bulk organic mass between the particle and gas phases is traditionally modeled with an equilibrium partitioning approach taking into account absorption into the OA phase, while typically neglecting growth by adsorption to particle surfaces (Pankow, 1994; Odum et al., 1996; Seinfeld and Pandis, 2006). In order to use this approach to model atmospheric OA, one must account for the volatility of any modeled semi-volatile organic, whether it originates directly from an emission source (primary organic aerosol or POA) (Robinson et al., 2007) or is formed from the oxidation of organic compounds too volatile to readily condense (secondary organic aerosol or SOA) (Odum et al., 1996; Griffin et al., 1999). Because these models treat the absorption of constituents into a bulk aerosol phase, the addition of mass to the absorbing phase enhances the particle-phase partitioning of individual species. In theory, one could enumerate and model every one of the thousands of individual organic compounds that contribute to OA formation and obtain an accurate prediction of OA mass concentrations. However, in practice, this approach would make computation times impractically long and require a wealth of experimental data that does not exist. Current models instead lump mass from compounds that are believed to behave similarly in the atmosphere (e.g. terminal alkenes or SOA from anthropogenic sources). Some models use heavily lumped approaches to further streamline computation time, but run the risk of losing information about contributions from specific sources and interactions between them (e.g. mixing behavior). Thus, models exist on a spectrum from ones that describe broad, aggregate behavior (Pandis et al., 1992; Binkowski and Roselle, 2003; Gaydos et al., 2007) to ones that describe more detailed chemistry (Griffin et al., 2005). A major challenge for the field of atmospheric aerosol modeling is to find an acceptable, reasonably performing balance between these two extremes.

Recently, the volatility basis set framework was developed to describe OA absorptive partitioning by organizing the total OA mass into surrogates along an axis of volatility (Donahue et al., 2006; Stanier et al., 2008). This approach typically employs species with effective saturation concentrations separated by one order of magnitude while spanning atmospherically relevant saturation concentrations (about 0.01 to $10^{6} \mu \mathrm{g} \mathrm{m}^{-3}$ ). Several studies have found this framework a useful approximation for describing both formation of secondary organic aerosol (SOA) (Presto and Donahue, 2006; Pathak et al., 2007; Stanier et al., 2008; Chan et al., 2009; Hildebrandt et al., 2009; Shilling et al., 2009) and evaporation of semivolatile primary organic aerosol (POA) constituents (Shrivastava et al., 2006, 2008; Robinson et al., 2007; Grieshop et al., 2009) as well as for modeling am- bient OA formation and chemical aging processes (Lane et al., 2008; Murphy and Pandis, 2009; Cappa and Jimenez, 2010; Farina et al., 2010; Tsimpidi et al., 2010). One major advantage of this framework is its focus on volatility, the most important property for determining the condensed fraction of an organic compound. Compounds with widely varying emission sources and otherwise different properties can be lumped into these saturation concentration bins and a straight-forward prediction of OA mass concentrations is possible. Moreover, the VBS can easily describe, at least to a first approximation, organic oxidation processes (aging) occurring in the actual atmosphere after the initial oxidation step observed in smog chamber investigations. Experiments suggest that this additional processing may reduce the overall volatility of organic compound populations considerably depending on the OA source and experimental conditions (temperature, relative humidity, $\mathrm{NO}_{\mathrm{x}}$ mixing ratios, etc.). It is straight-forward to use the VBS to transfer mass from one volatility bin to another and thus affect the overall OA concentration. However, experimentally determined reaction rates and yields for these processes are uncertain and their magnitudes are likely dependent on compound properties as well as environmental conditions. It is thus useful to combine atmospheric modeling sensitivity studies with constraints from experiments and ambient measurements in order to reduce the current uncertainty in homogenous gasphase aging of organic compounds.

Recent developments in OA measuring techniques have seriously increased analytical capabilities of smog chamber and ambient OA investigations. Specifically, the aerosol mass spectrometer (AMS) and the thermodenuder systems provide detailed information about the average chemical composition and volatility distribution of OA. Using the AMS, field campaigns throughout the world have found that ambient OA has high oxygen content, indicating extensive oxidation during its atmospheric lifetime (Zhang et al., 2007; Kroll et al., 2011). Thermodenuder studies have found OA in the field to be quite low in volatility, also indicative of extensive oxidation and addition of polarizing functional groups (Huffman et al., 2009; Lee et al., 2010). However, these same instruments deployed in smog chamber studies tend to observe OA that is somewhat lower in oxygen content and higher in volatility (Jimenez et al., 2009). It is quite possible that continued atmospheric oxidation would help explain both of these inconsistencies. Moreover, if this continued oxidation tends to decrease the average volatility of atmospheric OA populations, then the subsequent mass enhancement (which would be more pronounced in summer periods with higher photochemical activity) may help close the gap in mass concentration between models and ambient measurements. However, as discussed above, the required parameters for describing these processes in a framework like the VBS are highly uncertain. There are many possible combinations of reaction rates and stoichiometric yields (transformations in volatility space) that would predict results consistent with 
chamber observations (Dzepina et al., 2009; Grieshop et al., 2009). The two-dimensional volatility basis set (2D-VBS) tracks the oxygen content as well as the saturation concentration of model species (Donahue et al., 2011), and this additional information could be used to compare predictions to the results from AMS observations. Simulating this added dimension may help constrain some of the uncertainties in OA aging as well as provide more precise predictions of the concentration of organic carbon, which is reported by ambient monitoring networks (Chow et al., 2001; Watson et al., 2005).

The major advantage of extending the VBS to describe oxygen content is the ability to quantify the degree of oxygenation. In this study, we will characterize this value as the ratio of oxygen to carbon atoms (O:C). Previous modeling efforts have implemented OA aging in the one-dimensional VBS (1D-VBS) and found it to improve predictions of the high degree of oxygenation in the ambient. However, this analysis was based only on estimating the fractional contribution of species that had never been oxidized in the model versus species that had been oxidized at least once. The current study performs a more rigorous analysis in which the extent of oxygenation is predicted and evaluated. There are many uncertainties associated with this effort including the initial O:C distribution of OA constituents and the change in $\mathrm{O}: \mathrm{C}$ with every aging generation. The hydroxyl radical can also be taken up into the organic particulate phase and react with condensed phase organic compounds, thereby altering their volatility and enhancing their oxygen content. $\mathrm{OH}$ uptake to condensed organic compounds has been studied in many experimental setups including uptake on organic surfaces (Bertram et al., 2001) to particles in a flow tube (George et al., 2007, 2008; Kroll et al., 2009; George and Abbatt, 2010) and in smog chambers (Lambe et al., 2007). A modest range of uptake coefficients have been measured and reported in the literature but a lifetime for exposure to $\mathrm{OH}$ of about 6 days $\left(k_{\mathrm{OH}} \approx 2 \times 10^{-12} \mathrm{~cm}^{3} \mathrm{molec}^{-1} \mathrm{~s}^{-1}\right.$ with $[\mathrm{OH}]=10^{6} \mathrm{molec}^{-3}$ ) is largely representative of these findings. This reaction rate constant is much lower than the base-case homogeneous $\mathrm{OH}$ reaction rate constant (George and Abbatt, 2010). It is therefore not expected that heterogeneous oxidation (by this pathway) will be significant near urban areas and large OA sources. However, after significant atmospheric transport, heterogeneous aging may increase the oxygenation of condensed phase material considerably.

Oxidation of biogenic VOCs like isoprene, monoterpenes and sesquiterpenes is a significant source of SOA at both global and regional scales, especially outside of urban areas. Therefore representing the atmospheric behavior of these SOA components accurately in models is crucial for predicting the total OA budget well. Smog chamber experiments have observed reductions in volatility and enhancements in oxygen content of biogenic SOA from multiple generation oxidation by the $\mathrm{OH}$ radical (Qi et al., 2010). Murphy and Pandis (2010) found that PMCAMx-2008, a regional-scale CTM that models OA aging with the 1DVBS, reproduced observed OA mass concentrations in urban and rural areas well when anthropogenic SOA aging with the base-case $\mathrm{OH}$ reaction rate constant was taken into account but tended to overpredict when biogenic SOA aging was included as well. When aging of SOA from both sources was included with a reduced reaction rate constant $\left(k_{\mathrm{OH}}=2.5 \times 10^{-12} \mathrm{~cm}^{3} \mathrm{molec}^{-1} \mathrm{~s}^{-1}\right)$, performance was comparable to the base case, but slightly worse. We will look at both of these cases to see the affect of including biogenic SOA (bSOA) aging in this 2D-VBS aging framework.

The 2D-VBS requires many more model species than its 1D counterpart, and so computation time becomes an important concern. Thus, we will first use this framework in a host transport model with reduced spatial dimensionality in order to evaluate the usefulness of this approach for modeling regional-scale OA behavior. The Finokalia Aerosol Measurement Experiment (FAME-08), which took place in May 2008 on the island of Crete, measured ambient OA with an AMS and thermodenuder, providing hourly simultaneous information about O:C and volatility (Pikridas et al., 2010). Measurements from the campaign indicate extensive, consistent OA aging with high O:C, low volatility and little diurnal variation (Hildebrandt et al., 2010; Lee et al., 2010). Thus this episode is a good candidate for a proof of concept modeling evaluation of the 2D-VBS and its capabilities.

We present in this work an implementation of the 2D-VBS within a one-dimensional Lagrangian transport host model to describe ambient organic aerosol formation and oxidative aging. We use extensive observations of the OA chemical composition during the FAME-08 study in order to evaluate the model's ability to accurately predict the average degree of oxygenation of bulk OA. We have chosen a suite of alternative model formulations that probe the major uncertainties of the 2D-VBS approach to understand their impacts on the model's prediction of total OA mass and extent of oxidation. Knowing the magnitude of these impacts, we recommend areas where detailed experimental characterization would lead to significant improvement in accuracy for ambient OA models.

\section{Organic aerosol module}

\subsection{Two-dimensional volatility basis set framework}

The traditional VBS framework of segregating OA surrogates based on effective saturation concentration, or $C^{*}$, is extended here to resolve OA mass in terms of $\mathrm{O}: \mathrm{C}$ as well. We assume organic compounds can range in $\mathrm{O}: \mathrm{C}$ from very low (fresh emissions) to $\mathrm{O}: \mathrm{C}>1$ (highly oxygenated species). This $2 \mathrm{D}-\mathrm{VBS}$ implementation resolves OA mass into 13 discrete linearly spaced $\mathrm{O}: \mathrm{C}$ bins varying from 0 to 1.2. One could extend the $\mathrm{O}: \mathrm{C}$ range up to $2\left(\mathrm{CO}_{2}\right)$; however, we are not aware of observations of OA species at these 
exceptionally high levels of oxygenation. Few ambient AMS data reveal O:C of bulk OA to be above 1.1 (Ng et al., 2010; Kroll et al., 2011).

Donahue et al. (2006) and Stanier et al. (2008) recommended choosing saturation concentration bins separated by an order of magnitude in $C^{*}$ space. Lane et al. (2008) chose to use four bins $\left(C^{*}=1\right.$ to $\left.1000 \mu \mathrm{g} \mathrm{m}^{-3}\right)$ to represent SOA production from volatile precursors since most atmospherically relevant chamber experiments focus on OA loadings in this range. Shrivastava et al. (2008) expanded this range $\left(C^{*}=0.01\right.$ to $\left.10^{6} \mu \mathrm{g} \mathrm{m}^{-3}\right)$ in order to better represent evaporation of POA mass explored in dilution experiments (Lipsky and Robinson, 2006). Cappa and Jimenez (2010) employed a wider $C^{*}$ range $\left(10^{-15}\right.$ to $\left.1000 \mu \mathrm{g} \mathrm{m}^{-3}\right)$ for their model of ambient OA mass from Mexico City and Los Angeles passing through a thermodenuder. Since the current work involves evaporation of POA emissions, emission of intermediate volatility organic compounds $\left(C^{*}=10^{3}\right.$ to $10^{6} \mu \mathrm{g} \mathrm{m}^{-3}$ ), and comparison to thermodenuder data taken during the FAME-08 campaign, we choose $C^{*}=10^{-5}$ to $10^{6} \mu \mathrm{g} \mathrm{m}^{-3}$ (12 total bins). The module will thus be able to capture phenomena relevant to several different volatility regimes.

The following five OA source classes are resolved: (1) aSOA is OA formed from the oxidation products of anthropogenic VOCs (aromatics, alkenes and alkanes), (2) bSOA is OA formed from oxidation products of biogenic VOCs (isoprene, monoterpenes and sesquiterpenes), (3) POA is fresh emitted OA with $C^{*} \leq 1000 \mu \mathrm{g} \mathrm{m}^{-3}$. This mass may evaporate and recondense during its atmospheric lifetime, but once it reacts with $\mathrm{OH}$ it is removed from this classification becoming (4) semi-volatile SOA (sSOA). (5) intermediate volatility SOA (iSOA) mass is emitted largely in the gas phase with $C^{*}>1000 \mu \mathrm{g} \mathrm{m}^{-3}$. This material, following Tsimpidi et al. (2010) is in equilibrium with emitted particulate OA mass. Because of the difficulty in measuring mass in this volatility range, emission inventories do not include these compounds. We thus add an additional 1.5 times the original POA mass emission rate to the intermediate volatility organic gas emission rate following several past studies (Robinson et al., 2007; Murphy and Pandis, 2009; Hodzic et al., 2010; Tsimpidi et al., 2010). In the gas phase, this mass is susceptible to oxidation by $\mathrm{OH}$ and may go to lower volatility and condense to form SOA.

One source of uncertainty for SOA formation is the initial $\mathrm{O}: \mathrm{C}$ distribution for 1st-generation products of organic gas oxidation. Mass from the oxidation of anthropogenic and biogenic VOCs is assigned an O:C equal to 0.4 consistent with smog chamber AMS measurements (Hildebrandt et al., 2009; Kostenidou et al., 2009). Grieshop et al. (2007) found that polarity for SOA components from $\alpha$-pinene ozonolysis increased with decreasing volatility. Kostenidou et al. (2009) used a thermodenuder in tandem with an AMS to segregate $\mathrm{O}: \mathrm{C}$ by volatility for SOA from traditional monoterpene precursor oxidation and found higher $\mathrm{O}: \mathrm{C}$ for lower volatility products in general. A similar conclusion was reached by Shilling et al. (2009) who used a continuous flow chamber with varied SOA loadings instead. The uncertainty in our assumption of volatility independent initial SOA O:C of 0.4 will be evaluated in a sensitivity study using an initial O:C distribution that varies with volatility. Semi-volatile and intermediate volatility gases (compounds from evaporation of diluted POA mass) are assigned an $\mathrm{O}: \mathrm{C}=0$. The fate of the products from the $\mathrm{OH}$ oxidation of these gases in the $2 \mathrm{D}$ VBS is then calculated by assuming that the emitted gases age similarly to later generation compounds (discussed in the next section).

\subsection{Homogeneous oxidative aging}

The 2D-VBS framework describes the evolution of OA volatility and oxygen content by distributing mass along both axes (saturation concentration and $\mathrm{O}: \mathrm{C}$ ) when mass from any bin reacts with the $\mathrm{OH}$ radical. This study focuses primarily on homogeneous gas-phase aging because it occurs rapidly $\left(k_{\mathrm{OH}}=0.1-10 \times 10^{-11} \mathrm{~cm}^{3} \mathrm{molec}^{-1} \mathrm{~s}^{-1}\right)$ compared to estimates for heterogeneous reaction with $\mathrm{OH}$. Previous work with the 1D-VBS describe gas-phase $\mathrm{OH}$ aging using various approaches that typically act to reduce the volatility of the products compared to the reactant species. Lane et al. (2008), Shrivastava et al. (2008), and Murphy and Pandis $(2009,2010)$ used a 1-bin (or decade) volatility reduction per reaction. This approach will be used in the present study as the base-case scenario. The model must specify the transformation in O:C space as well. For the base case, we will assume that oxidation of the population by the $\mathrm{OH}$ radical will behave like $\mathrm{H}$-atom abstraction from alkanes. After the initial $\mathrm{H}$-atom abstraction and oxygen addition, the resulting alkyl peroxy radical can react with many gas-phase constituents like $\mathrm{NO}, \mathrm{NO}_{3}$, or other peroxy radicals to form an alkoxy radical (Atkinson, 2000). This alkoxy radical can then stabilize through reaction and result in a product species with one more oxygen than the precursor organic compound. On the other hand, the alkyl peroxy radical may react with $\mathrm{HO}_{2}$ to form a hydroperoxide that will have two more oxygen atoms than its precursor. We will assume for this basecase an equal probability of adding one or two oxygen atoms to the organic reactant molecule. In order to calculate the increase in $\mathrm{O}: \mathrm{C}$ for each added oxygen, the average carbon number of the reactant species must be known. Donahue et al. (2011) used structure activity relationships from the SIMPOL group contribution method (Pankow and Asher, 2008) to estimate vapor pressures as a function of carbon number and oxygen content. These trends can then be applied to the range of saturation concentration and $\mathrm{O}: \mathrm{C}$ used in the current work and a representative carbon number for every combination of $C^{*}$ and O:C can be estimated (Table 1). This representative carbon number can be used to calculate the average increase in O:C. This O:C will likely fall "between" the model $\mathrm{O}: \mathrm{C}$ bins so we interpolate between them and subsequently 
Table 1. Carbon number as a function of effective saturation concentration and $\mathrm{O}: \mathrm{C}$ in the 2D-VBS.

\begin{tabular}{rrrrrrrrrrrrr}
\hline O:C & \multicolumn{10}{c}{ Effective saturation concentration $\left(\mu \mathrm{g} \mathrm{m}^{-3}\right)$} \\
\hline & \multicolumn{1}{c}{$10^{-5}$} & $10^{-4}$ & $10^{-3}$ & $10^{-2}$ & $10^{-1}$ & $10^{0}$ & $10^{1}$ & $10^{2}$ & $10^{3}$ & $10^{4}$ & $10^{5}$ & $10^{6}$ \\
\hline 1.2 & 6.9 & 6.5 & 6.1 & 5.7 & 5.3 & 4.9 & 4.5 & 4.1 & 3.7 & 3.3 & 3.0 & 2.6 \\
1.1 & 7.4 & 7.0 & 6.5 & 6.1 & 5.7 & 5.3 & 4.9 & 4.4 & 4.0 & 3.6 & 3.2 & 2.7 \\
1.0 & 8.0 & 7.5 & 7.0 & 6.6 & 6.1 & 5.7 & 5.2 & 4.8 & 4.3 & 3.9 & 3.4 & 3.0 \\
0.9 & 8.6 & 8.1 & 7.6 & 7.1 & 6.7 & 6.2 & 5.7 & 5.2 & 4.7 & 4.2 & 3.7 & 3.2 \\
0.8 & 9.4 & 8.9 & 8.3 & 7.8 & 7.3 & 6.7 & 6.2 & 5.6 & 5.1 & 4.6 & 4.0 & 3.5 \\
0.7 & 10.4 & 9.8 & 9.2 & 8.6 & 8.0 & 7.4 & 6.8 & 6.2 & 5.6 & 5.0 & 4.4 & 3.8 \\
0.6 & 11.5 & 10.9 & 10.2 & 9.5 & 8.9 & 8.2 & 7.6 & 6.9 & 6.3 & 5.6 & 5.0 & 4.4 \\
0.5 & 13.0 & 12.2 & 11.5 & 10.7 & 10.0 & 9.3 & 8.5 & 7.8 & 7.0 & 6.3 & 5.6 & 4.9 \\
0.4 & 14.8 & 14.0 & 13.1 & 12.3 & 11.4 & 10.6 & 9.7 & 8.9 & 8.1 & 7.2 & 6.3 & 5.6 \\
0.3 & 17.3 & 16.3 & 15.3 & 14.4 & 13.4 & 12.4 & 11.4 & 10.4 & 9.4 & 8.4 & 7.4 & 6.4 \\
0.2 & 20.8 & 19.6 & 18.5 & 17.3 & 16.1 & 14.9 & 13.7 & 12.5 & 11.3 & 10.1 & 8.9 & 7.7 \\
0.1 & 30.5 & 28.8 & 27.1 & 25.3 & 23.6 & 21.9 & 20.1 & 18.3 & 16.6 & 14.9 & 13.1 & 11.4 \\
\hline
\end{tabular}

split the mass between the two adjacent bins for each oxygen added. This approach introduces some numerical diffusion, but the OA aging process is expected to "diffuse" mass throughout the 2D-VBS space so this is an acceptable result. The O:C increase due to oxidation by $\mathrm{OH}$ changes depending on where in the 2D-VBS space the reactant species is. An OA species with the same volatility but higher O:C than another OA species presumably has fewer carbons since the greater functionality will act to reduce its volatility. Thus it will increase more in $\mathrm{O}: \mathrm{C}$ when oxygen atoms are added than a larger hydrocarbon.

Shrivastava et al. (2008) and Murphy and Pandis (2010) employed an $\mathrm{OH}$ reaction rate constant equal to $1 \times 10^{-11}$ for aSOA and $4 \times 10^{-11} \mathrm{~cm}^{3} \mathrm{molec}^{-1} \mathrm{~s}^{-1}$ for $\mathrm{sSOA}$ and iSOA species in PMCAMx-2008, and found the model to reasonably reproduce observed OA concentrations in the summer and winter. The same rates are used for the current model in the base case. For bSOA, the model does simulate the oxygenation of this mass as it reacts with $\mathrm{OH}$, but assumes that these reactions increase $\mathrm{O}: \mathrm{C}$ without a net change of the volatility of the products. These gases are aged with the same rate constant used for aSOA aging. When modeling OA with the 1D-VBS, the amount of mass added for each generation of oxidation must be assumed. Lane et al. (2008) assumed each addition of oxygen adds $7.5 \%$ of the reactant mass. Grieshop et al. (2009) used $7.5 \%$ and $40 \%$ added mass for fitting their chamber results to the 1- and 2-bin volatility reduction models, respectively. Resolving the basis set framework along the O:C axis allows explicit calculation of this added mass. Assuming carbon is conserved when mass is moved up in O:C, the new organic matter (carbon, hydrogen, and oxygen) mass can be calculated as:

$[\mathrm{OM}]_{\text {Final }}=\left[\frac{\mathrm{OM}}{\mathrm{OC}}\right]_{\text {Final }}[\mathrm{OM}]_{\text {Initial }}\left(\left[\frac{\mathrm{OM}}{\mathrm{OC}}\right]_{\text {Initial }}\right)^{-1}$

where $\mathrm{OM}$ is the organic matter and $\mathrm{OC}$ is the organic carbon concentration. The OM/OC before and after oxidation can be calculated knowing the $\mathrm{O}: \mathrm{C}$ of both the initial and final organic species:

$\left[\frac{\mathrm{OM}}{\mathrm{OC}}\right]=1+\frac{16}{12}[\mathrm{O} / \mathrm{C}]+\frac{1}{12}[\mathrm{H} / \mathrm{C}]$

where $\mathrm{O} / \mathrm{C}$ is the $\mathrm{O}: \mathrm{C}$ of the species of interest, and $\mathrm{H} / \mathrm{C}$ is the ratio of moles of hydrogen to moles of carbon. This relationship assumes that the presence of organic nitrate will not significantly alter this approximation. Also, we will assume that $\mathrm{H}: \mathrm{C}$ is a function of $\mathrm{O}: \mathrm{C}$ :

$[\mathrm{H} / \mathrm{C}]=2-[\mathrm{O} / \mathrm{C}]$

following Heald et al. (2010) who determined analyzing AMS field data that, on average, one hydrogen atom is lost from a population of organics for every gain of one oxygen atom.

\subsection{Alternative homogeneous oxidative aging configurations}

This study will also explore the uncertainty in the O:C and volatility distribution predictions due to the specific aging configuration chosen. Grieshop et al. (2009) and Hodzic et al. (2010) investigated both the 1-bin base-case saturation concentration reduction as well as a 2-bin reduction with a reduced $\mathrm{OH}$ reaction rate constant and found both to perform adequately. We assume that this 2-bin reduction in volatility is accompanied by an addition of 2 or 3 oxygen atoms, each with equal probability, and we divide all of the base-case aging rate constants by a factor of 2 . The 1- and 2-decade volatility shift scenarios reflect similar model scenarios in that for every reaction with $\mathrm{OH}$ their proportional enhancement in $\mathrm{O}: \mathrm{C}$ for a given reduction in volatility are similar. Therefore, we will also present the following two sensitivity cases: (1) a 1-bin volatility shift with a $40 \%$ and 
$60 \%$ probability of adding 3 or 4 oxygen atoms, respectively to explore the possibility of rapid oxygen addition with low reduction in volatility and, (2) a 2-bin volatility shift with a $60 \%$ and $40 \%$ probability of adding 1 or 2 oxygen atoms, respectively to explore the scenario where few oxygen additions are needed to substantially reduce the volatility.

A fourth sensitivity study will examine the affect of assuming aging of bSOA does not change its volatility. For this analysis, bSOA species are aged with the same mechanism and rate constant used for aSOA aging. When both of these species are aged with the base-case $\mathrm{OH}$ reaction rate in the 1D-VBS framework, model predictions generally overshoot ambient measurements (Murphy and Pandis, 2010). We will study a case where all SOA is aged with the base-case reaction rates and then explore a second case with $\mathrm{OH}$ rate constants reduced by a factor of 4 .

\subsection{Heterogeneous oxidative aging}

The impact of heterogeneous-phase oxidation by $\mathrm{OH}$ uptake directly to OA species will be explored by employing the same aging mechanism as for the base case with an equivalent homogeneous $\mathrm{OH}$ aging rate constant $\left(k_{\mathrm{OH}}=\right.$ $2 \times 10^{-12} \mathrm{~cm}^{3} \mathrm{molec}^{-1} \mathrm{~s}^{-1}$ ) for all species in the particulate phase (Lambe et al., 2007; Weitkamp et al., 2008). This process, although significantly slower than its gas-phase analogue, may be able to significantly enhance the average $\mathrm{O}: \mathrm{C}$ of the bulk OA population after much of the highly oxygenated mass has condensed and is no longer available for continued gas-phase oxidation. This sensitivity case assumes, as a first approximation, that heterogeneous phase aging only adds functional groups to the OA species and does not lead to fragmentation and enhanced evaporation of OA mass. Other processes that would affect OA formation rates may also be occurring in the particulate phase including accretion combinations and reactions in the aqueous phase with hydrophilic organic species like glyoxal. These systems should be further explored in future studies.

\section{Application to the FAME-08 campaign}

\subsection{Measurements}

FAME-08 was conducted from 8 May to 4 June 2008 and continuously measured chemical and physical characteristics of PM, air ions, gaseous species and meteorological parameters (Pikridas et al., 2010). No distinct variation was seen in relative humidity or wind speed, but intense solar radiation was observed with daily maxima always exceeding $850 \mathrm{~W} \mathrm{~m}^{-2}$. This feature of the FAME-08 campaign makes it a desirable scenario for the initial testing of the 2D-VBS OA aging module.

The non-refractory $\mathrm{PM}_{1}$ chemical composition was measured with an Aerodyne quadropole aerosol mass spectrometer (Q-AMS) as described in detail by Hildebrandt et al. (2010). Using the organic mass at $\mathrm{m} / \mathrm{z} 44$ as measured by the Q-AMS, that study estimated O:C with the parameterization of Aiken et al. (2008). The contribution from $\mathrm{m} / \mathrm{z}$ 57 (characteristic of fresh, hydrocarbon-like organic species) was barely detectable throughout the campaign, indicating heavily aged organic aerosol was arriving at the site regardless of the source location.

Measurements of the OA volatility with a thermodenuder were obtained simultaneously with the AMS chemical composition observations and are documented by Lee et al. (2010). The OA observed had low volatility (approximately two orders of magnitude less volatile than laboratorygenerated $\alpha$-pinene SOA). Comparing the $C^{*}$ distribution predicted by the 2D-VBS with a fit obtained from the thermodenuder observations is ill-constrained. Instead, the final $C^{*}$ distribution of OA arriving at the Finokalia receptor site is used, along with the size distribution of OA mass as input to a dynamic mass transfer model of a thermodenuder system (Riipinen et al., 2010). This model is then used to predict the fraction of initial OA remaining (MFR) after exposure to the elevated thermodenuder temperature. The thermodenuder model also needs as input the thermodenuder temperature and residence time as well as the enthalpies of vaporization and accommodation coefficients of the OA constituents. The 2D-VBS model assumes enthalpies of vaporization for every organic species, so it makes sense to keep this parameter consistent between the transport model and the thermodenuder model. A range of vaporization enthalpy inputs to the thermodenuder model will also be explored when comparing MFR predictions to the FAME-08 observations.

\subsection{Lagrangian transport model}

The 2D-VBS organic aerosol module has been added to a one-dimensional Lagrangian transport model which simulates air parcels as they arrive at a receptor site. The Finokalia site during the FAME-08 campaign in May 2008 will be used here. Previous versions of this host model have been applied to California in efforts to develop predictive modules for processes such as SOA formation (Strader et al., 1999; Koo et al., 2003) and gas/particle partitioning of atmospheric pollutants (Gaydos et al., 2003). The model takes into account relevant atmospheric processes including gasphase chemistry (using SAPRC-99), dry and wet deposition, and vertical turbulent dispersion. Removal processes have been updated with treatments similar to those in PMCAMx2008 (Gaydos et al., 2007). The 10 grid cell column reaches $2.5 \mathrm{~km}$ in the atmosphere with the first cell top boundary at $60 \mathrm{~m}$. Gridded inputs were obtained for a domain including the entire European continent as well as parts of northern Africa and western Asia. All of the meteorological parameters (horizontal winds, vertical dispersion coefficients, temperature, pressure, water vapor, clouds, and rainfall) input to this model are calculated by the Weather Research and Forecasting (WRF) Model (Skamarock et al., 2008). WRF 


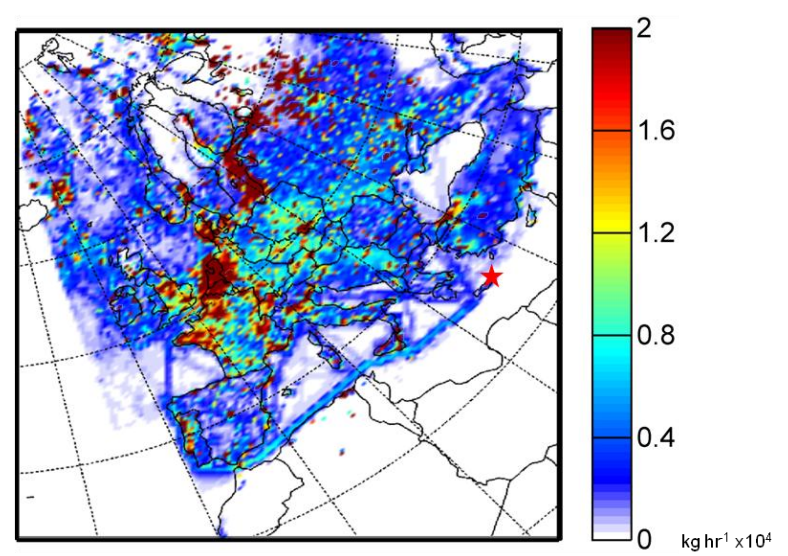

Fig. 1. Hourly averaged primary organic aerosol bulk emissions for the European domain during the EUCAARI period (May 2008). The red star indicates the location of the FAME-08 measurement site.

was driven by static geographical data and dynamic meteorological data (near real-time and historical data generated by the Global Forecast System $\left(1 \times 1^{\circ}\right)$. Twenty-seven sigma- $p$ layers up to 0.1 bars were used in the vertical dimension. The WRF May 2008 run was periodically re-initialized (every 3 days) to ensure accuracy in the corresponding fields that are used as inputs to this Lagrangian model.

Anthropogenic and biogenic emissions are input as hourly gridded fields (Fig. 1). Anthropogenic gases include land emissions from the GEMS dataset (Visschedijk et al., 2007) and emissions from international shipping activities. Anthropogenic particulate matter mass emissions of organic and elemental carbon are based on the Pan-European Carbonaceous Aerosol Inventory that has been developed as part of the EUCAARI activities (Kulmala et al., 2009). Three different datasets are combined in order to produce the biogenic gridded emissions for the model. Emissions from ecosystems are produced offline by the Model of Emissions of Gases and Aerosols from Nature (MEGAN) (Guenther et al., 2006). Since sea surface covers a considerable portion of the domain, the marine aerosol model developed by O'Dowd et al. (2008) has been used with the submicron aerosol sea spray source function from Geever et al. (2005) to estimate mass fluxes for both accumulation and coarse mode including the organic aerosol fraction. Wind speed data from WRF and chlorophyll-a concentrations are the inputs needed for the marine aerosol model. Wildfire emissions from May 2008 were also included (Sofiev et al., 2008a,b).

Six parcels arriving at 03:00, 07:00, 11:00, 15:00, 19:00, and 23:00 h local time (UTC $+2 \mathrm{~h}$ ) are simulated for 9 campaign days $(9,12,15,16,17,26,27,28$ and 29 May). These days are chosen because AMS and thermodenuder data were available, and the air masses originated from Europe (emissions inventories for northern Africa are quite uncertain). The Hybrid Single Particle Lagrangian Integrated Trajectory
(HYSPLIT) model (Draxler et al., 2009) is used to calculate $72 \mathrm{~h}$ back trajectories for each arriving air parcel. For consistency, this study uses the same meteorological fields (calculated by WRF) as input to the HYSPLIT model to calculate the back trajectories. One source of uncertainty in calculating back-trajectories is wind shear along the parcel path. Because of this phenomenon, a parcel initialized at the Earth's surface may have a different spatial origin than one initialized at $1 \mathrm{~km}$. These parcels in theory may have accumulated different pollutant levels, been exposed to different weather conditions, etc. To help mitigate this issue, 20 trajectories are calculated for each arrival time by varying the height of the arriving parcel from ground level to the $2.5 \mathrm{~km}$ model ceiling (Fig. 2a). The HYSPLIT clustering analysis utility is then used to estimate the path of one trajectory that best represents the origins of the 20 sample trajectories simultaneously (Fig. 2b).

Each trajectory is started $72 \mathrm{~h}$ before it arrives at the receptor site and initialized with pollutant concentrations output from a PMCAMx-2008 simulation of the European domain that are matched specifically to that location and time. As the modeled air parcel proceeds through the path calculated by HYSPLIT, it accumulates pollutant emissions determined by the hourly gridded inventories. Another source of uncertainty arises from the lack of horizontal dispersion in this approach. At later model times, when the parcel is near the receptor site, it is possible that only the emissions dictated by the actual grid the parcel is located in will have an effect on the concentrations experienced at Finokalia. At the other extreme, for earlier model times, when the parcel is far away from the site, it is likely that a wide area of sources contributes to pollutants that will eventually affect levels at the receptor site. The trajectories in Fig. 2a illustrate this divergence as they go back in time. To overcome this weakness, a larger area of grid cells is taken into account at each time step when calculating the average emissions experienced by the parcel. This area begins as a diamond 24 grid cells wide and centered on the parcel's present grid cell. As the model moves forward in time, the sample size decreases until it uses only the parcel grid cell to inform pollutant emission rates for the last six model hours. PMCAMx-2008 includes an additional OA model species that is advected from outside the model boundaries. This species, boundary condition OA (bcOA), is assumed to be highly aged and essentially non-volatile. Its concentrations at the boundaries in PMCAMx-2008 are kept constant horizontally and through time, but do vary in height generally consistent with observed vertical profiles (Morgan et al., 2010). For this study, the O:C of bcOA will be assumed equal to the bulk average of all other OA species. This assumption should be revisited when applying this model to urban areas with lower O:C values, but will have little effect on predictions of highly aged OA at the Finokalia station. The likely source for this species is long-range transport from other continents as well as marine-source OA mass. 


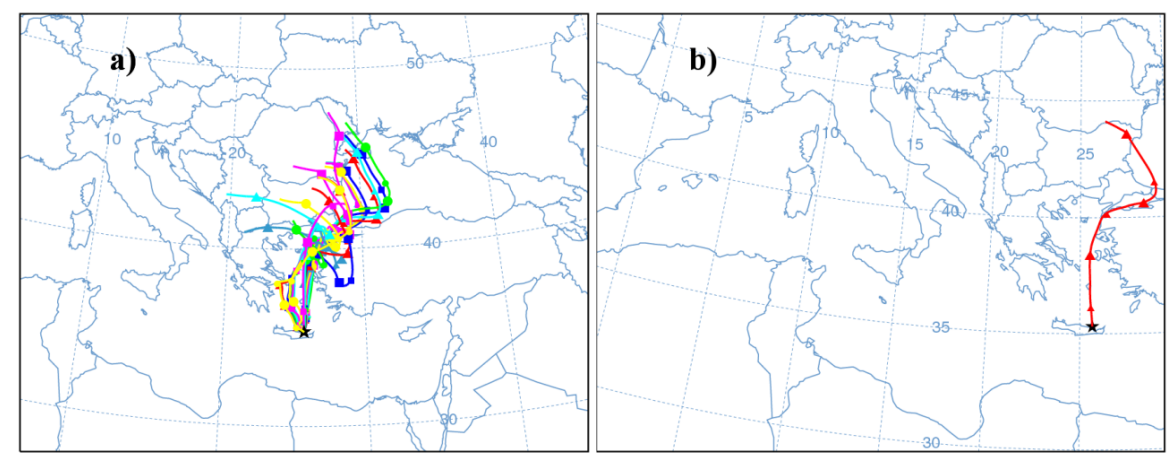

Fig. 2. 72-h back-trajectories calculated in HYSPLIT with WRF gridded meteorological input data for parcels arriving at the Finokalia site during the FAME-08 campaign on 15 May 2008 at 05:00 p.m. UTC. (a) 20 back-trajectories are simulated with varying arrival altitude. (b) These paths are then combined with the HYSPLIT clustering utility to estimate one representative trajectory for the parcel's horizontal path.

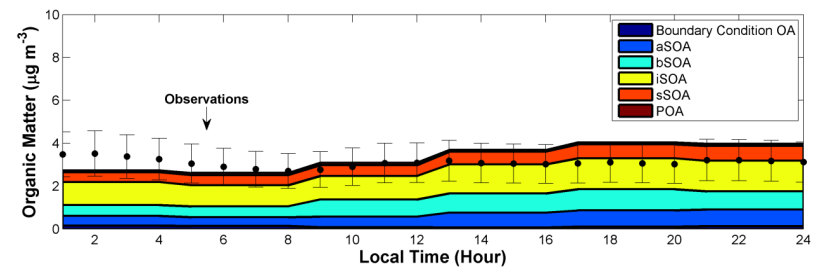

Fig. 3. Diurnally averaged organic aerosol mass concentrations for the FAME-08 period segregated by source class. Also shown are the measurements taken by the AMS with the corresponding uncertainty range.

\section{Results}

\subsection{Organic aerosol mass concentrations}

The predicted diurnally averaged organic aerosol source profile for the base-case simulations is consistent with the AMS measurements during the FAME-08 study (Fig. 3). The base-case average predicted OA concentrations of $3.3 \mu \mathrm{g} \mathrm{m}^{-3}$ agrees reasonably with the measured concentration, $3.1 \mu \mathrm{g} \mathrm{m}^{-3}$. Moreover, the model results exhibit little variability throughout the day although slightly more than that of the measurements. Anthropogenic sources clearly dominate the OA contribution for this case, with aSOA, iSOA, sSOA, and POA accounting for 17.8, 36.6, 16.7 and $2.9 \%$, respectively. bSOA is predicted to contribute $22.7 \%$ to the total OA arriving at Finokalia on average during this period. The emission source strength of the IVOC precursors that lead to this mass is quite uncertain as are its aging parameters. The very small contribution from fresh POA due to semivolatile partitioning and oxidation is consistent with the observations of Hildebrandt et al. (2010) during FAME-08.

\subsection{Organic aerosol O:C, volatility distributions}

The predicted O:C distribution (Fig. 4a) shows a wide distribution with at least three, perhaps four, peaks throughout the day. Aging of POA, which is initialized at 0 in O:C creates a peak at about 0.2 , while the fresh SOA leads to a clear peak at 0.4 and perhaps another at 0.5 indicative of aged compounds that have condensed and are no longer subject to homogeneous $\mathrm{OH}$ reaction. Some of the OA mass is predicted to reach an $\mathrm{O}: \mathrm{C}$ of 1.2, creating a peak at the top of the axis. When averaged, the predicted O:C of the population agrees well with observations both in terms of magnitude and trend throughout the day. The predicted value always falls within the estimated measurement error of $20 \%$.

If this predicted distribution is reflective of the actual ambient OA O:C distributions, it could indicate a weakness in describing the complexity of OA oxygen content with one averaged value. However, the strong peak at $\mathrm{O}: \mathrm{C}=1.2$ could also indicate unrealistically aggressive aging parameters that would continue to enhance the average $\mathrm{O}: \mathrm{C}$ and lead to $\mathrm{O}: \mathrm{C}$ overpredictions if they were not artificially held at 1.2 by the module boundaries. The model can also estimate the organic mass added per generation of oxidation. The average for this model is about $16 \%$ and fluctuates between 14 and $18 \%$ depending on proximity of the parcel to local emissions sources. This estimate falls between the assumptions of $7.5 \%$ and $40 \%$ for the one- and two-bin shift cases, respectively.

The predicted volatility distribution is similarly quite stable throughout a representative day of air parcels arriving from Europe during the FAME-08 study (Fig. 4b). The trend shows one consistent mode with a nearly constant average effective volatility $\left(C^{*}=0.6 \mu \mathrm{g} \mathrm{m}^{-3}\right)$ and a somewhat wide range (from $C^{*}=10^{-2}$ to $10^{2} \mu \mathrm{g} \mathrm{m}^{-3}$ ). For every arriving parcel, the final $C^{*}$ and size distributions are summed and input to the dynamic mass transfer thermodenuder model of Riipinen et al. (2010). Given the thermodenuder temperature 
and residence time used during the measurements, the model predicts the OA mass fraction remaining of particles in the arriving parcel. This value, diurnally averaged, is then directly compared to the measurements from the thermodenuder in Fig. 5. Two major sources of uncertainty for the thermodenuder model, the vaporization enthalpies $\left(\Delta H_{\mathrm{vap}}\right)$ and accommodation coefficients $(\alpha)$, are explored systematically in this figure. Only the base-case configuration of the transport model is used for input data here. In other words, for the data in this figure, the vaporization enthalpies are only varied in the thermodenuder model, not the Lagrangian model. Sensitivity to the enthalpy of vaporization in the Lagrangian model will be explored later. Three values for the enthalpy of vaporization $\left(30,50\right.$, and $\left.75 \mathrm{~kJ} \mathrm{~mol}^{-1}\right)$ and the accommodation coefficient $(0.05,0.5$, and 1$)$ are chosen to represent all OA species, independent of their volatility. Assuming a uniform $\Delta H_{\mathrm{vap}}=30 \mathrm{~kJ} \mathrm{~mol}^{-1}$ (Fig. 5a) is not consistent with any of the actual measurements, regardless of the choice of $\alpha$. It is thus suggested from this campaign that the base-case assumption of $30 \mathrm{~kJ} \mathrm{~mol}^{-1}$ is too low. Increasing $\Delta H_{\text {vap }}$ to $50 \mathrm{~kJ} \mathrm{~mol}^{-1}$ still overpredicts MFR observations in general, although some agreement is seen around noon for a representative day with $\alpha=1$ (the upper bound on $\alpha$ ). With $\Delta H_{\mathrm{vap}}=75 \mathrm{~kJ} \mathrm{~mol}^{-1}$, the model underpredicts the observed MFR (overpredicts evaporation) for cases with $\alpha \geq 0.5$. However, there are likely many model configurations that would lead to acceptable results as long as $\Delta H_{\text {vap }} \approx 75 \mathrm{~kJ} \mathrm{~mol}^{-1}$ and $0.05 \leq \alpha \leq 0.5$. Moreover, some error is introduced by assuming constant $\Delta H_{\mathrm{vap}}$ across all volatilities (Epstein et al., 2010). This analysis is not meant to actually recommend specific values for $\Delta H_{\mathrm{vap}}$ and $\alpha$, but does give insights into upper and lower bounds on these parameters and the reasonableness of the $2 \mathrm{D}-\mathrm{VBS}$ predictions.

To test the uncertainty introduced by our method of clustering 20 back-trajectories, we ran the model for each trajectory separately for an entire simulation day (16 May). We found some variability in the organic mass prediction with extreme estimates about $0.75 \mu \mathrm{g} \mathrm{m}^{-3}$ from the mean prediction. $\mathrm{O}: \mathrm{C}$ and volatility were much more stable with ranges of $\mathrm{O}: \mathrm{C} \pm 0.02$ and $\log _{10} C^{*} \pm 0.2$.

\subsection{Sensitivity studies}

\subsubsection{First generation product oxidation state distribution}

When the O:C distributions of first-generation VOC oxidation products are updated with yield estimates that vary with volatility (Table 2), little change in total OA mass or contribution from any particular OA source is seen. The average OA concentration decreases from 3.3 to $2.8 \mu \mathrm{g} \mathrm{m}^{-3}$ ( $\sim 15 \%$ decrease). This is due to the enhanced oxygen mass added in the base case from species that have the opportunity to reach high $\mathrm{O}: \mathrm{C}$ before condensing and being unavailable to further oxidation processes. The volatility distribution and diurnal
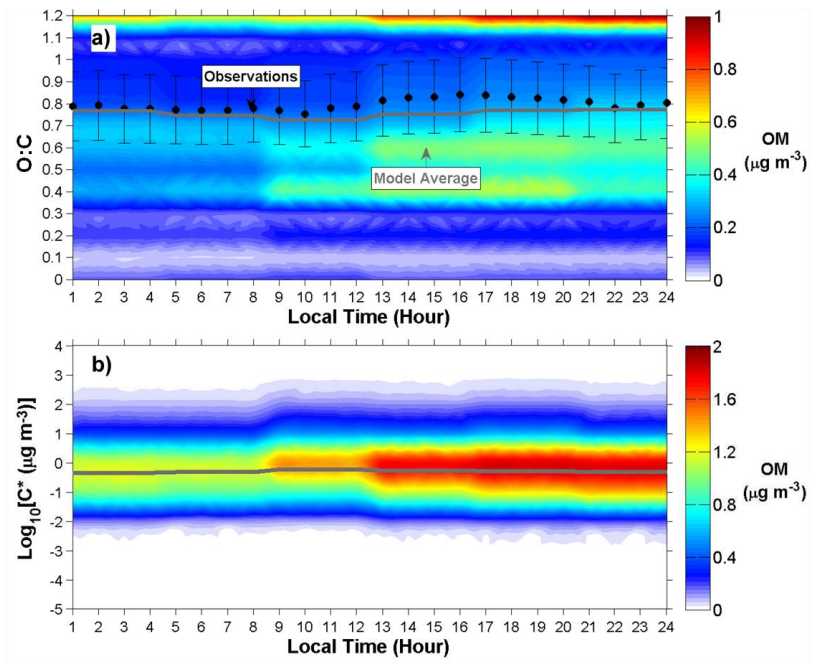

Fig. 4. Diurnally averaged (a) O:C distribution for a representative day during the Finokalia Aerosol Measurement Experiment. Black circles represent measurement averages while the gray line corresponds to the model average as it evolves throughout the day. Error bars denote $20 \%$ deviation from the measurement. (b) OA volatility distribution for the same representative day in May 2008. The gray line here represents the model average of the OA volatility.

Table 2. O:C Distributions for First-Generation SOA Products.

\begin{tabular}{lrrrr}
\hline$C^{*}\left(\mu \mathrm{g} \mathrm{m}^{-3}\right)$ & 1 & 10 & 100 & 1000 \\
\hline Anthropogenic SOA & 0.6 & 0.4 & 0.3 & 0.25 \\
Biogenic SOA & 0.4 & 0.24 & 0.14 & 0.1 \\
\hline
\end{tabular}

average is almost unchanged between the base case and this sensitivity test.

The predicted O:C diurnal average resulting from using the variable $\mathrm{O}: \mathrm{C}$ distributions for the first-generation products of VOC oxidation (Table 2) are shown in Fig. 6. Although there appears to be added mass at O:C lower than 0.4 , there does not seem to be an added peak. There is, however, a substantial reduction $(\sim 10-15 \%)$ in the average O:C throughout the day.

\subsubsection{SOA vaporization enthalpy}

Temperature sensitivity is an important concern in simulating OA formation, especially for predictions at high altitudes. Figure 7 shows, though, that for this period, surface concentration predictions are not very sensitive to the choice of SOA vaporization enthalpy. For this test, we only vary the aSOA

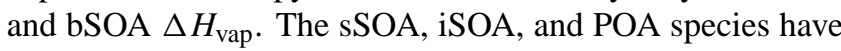
vaporization enthalpies that vary with volatility consistent with Murphy and Pandis (2009). As the enthalpy of vaporization is increased, the predicted $\mathrm{O}: \mathrm{C}$ consistently decreases, due to OA mass condensing that would have otherwise stayed 

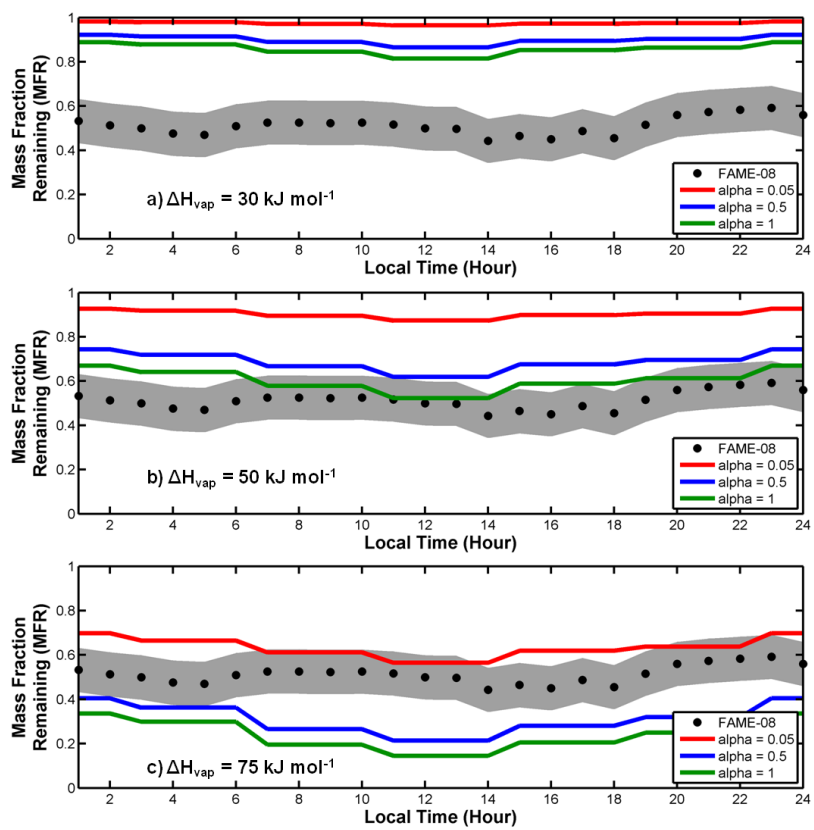

Fig. 5. Comparison of model predicted OA behavior in a thermodenuder to observations made during FAME-08. Black circles and gray area indicate measurement values and uncertainty, respectively. The transport model predictions for this base case assumes $\Delta H_{\mathrm{vap}}=30 \mathrm{~kJ} \mathrm{~mol}^{-1}$ for aSOA and bSOA species, regardless of volatility, while $\Delta H_{\mathrm{vap}}$ for POA, iSOA, and sSOA species varies linearly from 130 to $64 \mathrm{~kJ} \mathrm{~mol}^{-1}$ as effective saturation concentration increases from $C^{*}=10^{-5}$ to $10^{6} \mu \mathrm{g} \mathrm{m}^{-3}$. The dynamic mass transfer thermodenuder model (Riipinen et al., 2010) assumes all OA mass has $\Delta H_{\mathrm{vap}}=30 \mathrm{~kJ} \mathrm{~mol}^{-1}$ (a), $50 \mathrm{~kJ} \mathrm{~mol}^{-1}$ (b), or $75 \mathrm{~kJ} \mathrm{~mol}^{-1}$ (c).

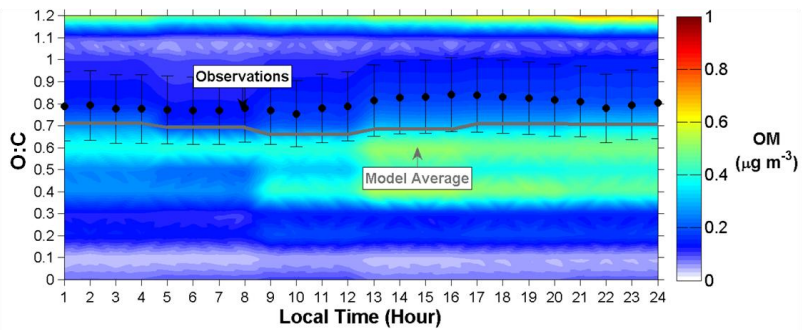

Fig. 6. Diurnally averaged O:C for a representative day during the FAME-08 campaign assuming an initial O:C that varies with volatility for first-generation organic products of VOC oxidation in the 2D-VBS.

in the gas phase until it were oxidized to greater functionality. The predicted organic mass concentrations do not change much compared to those of the base-case simulation and stay generally within measurement uncertainty for the entire day. The model predicted volatility distributions (not shown) are almost exactly the same for all of these cases. It is clear that for this analysis, constraining $\Delta H_{\text {vap }}$ is much more crit-
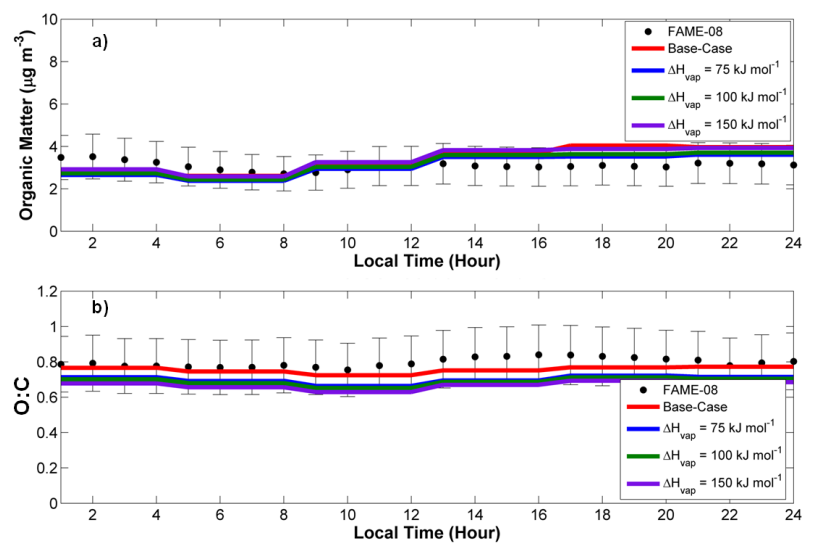

Fig. 7. (a) Organic aerosol mass concentrations and (b) O:C with several choices for anthropogenic and biogenic volatile SOA enthalpy of vaporization in the 2D-VBS configuration. All values are diurnally averaged for the 9 simulated days during FAME-08. Errors bars correspond to the measurements uncertainty.

ical for modeling thermodenuder behavior than for OA atmospheric behavior. This is not to say that the enthalpy of vaporization is unimportant for CTMs in general. It is quite important for models to correctly represent OA temperature sensitivity at high altitudes where cooling will lead to enhanced partitioning to the particulate phase.

\subsubsection{Homogeneous oxidative aging}

Two-bin volatility shift. The 2-decade reduction in volatility scenario results in a diurnal profile that performs nearly as well as the base case, although with the reduced aging rate constant (half of the base-case assumption) it slightly underpredicts the FAME-08 measurements (Fig. 8a). The average OA volatility is slightly reduced as well for this scenario compared to the base case $\left(0.20\right.$ and $0.63 \mu \mathrm{g} \mathrm{m}^{-3}$, respectively). This is somewhat less reduction than expected given the much larger jump in volatility for every generation of aging compared to the base-case aging configuration. OA mass appears to accumulate at effective saturation concentrations of approximately $0.1-1 \mu \mathrm{g} \mathrm{m}^{-3}$ because once it gets to this point, it is more likely found in the particulate phase and unable to react with gas-phase $\mathrm{OH}$. Thus, the full difference that might be anticipated in moving from a 1- to 2-decade shift in volatility is not realized. The average O:C (Fig. 8b) is also lowered compared to the base case in this test, and this result is probably due to the lack of the strong peak at $\mathrm{O}: \mathrm{C}=1.2$ seen in the base-case scenario. If this aging scenario is carried out with the base-case $\mathrm{OH}$ reaction rate constants instead of the reduced ones, the average OA mass increases substantially, from 2.8 to $3.7 \mu \mathrm{g} \mathrm{m}^{-3}$ but $\mathrm{O}$ :C agrees nearly exactly with the base case throughout the entire representative day. Increasing the reaction rate also reintroduces the strong peak of $\mathrm{OA}$ mass at $\mathrm{O}: \mathrm{C}=1.2$. It is possible that if homogeneous 

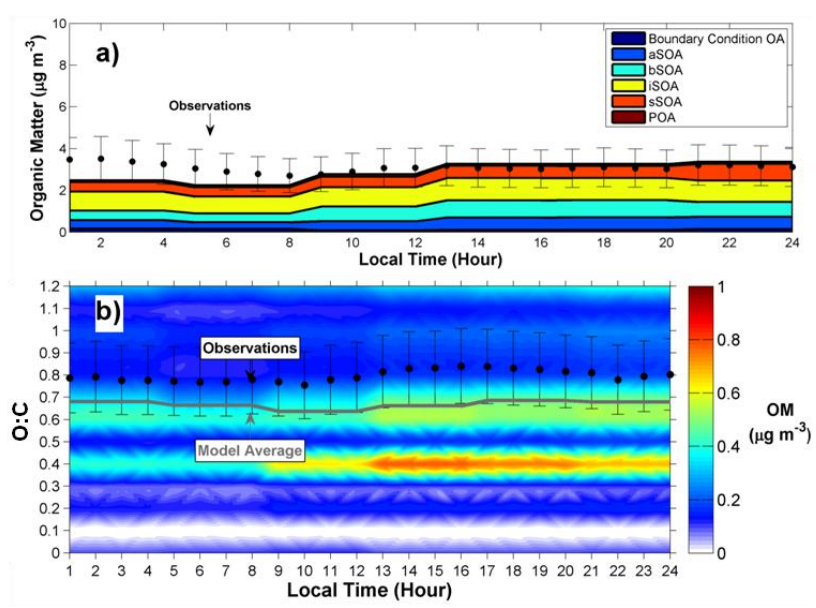

Fig. 8. Diurnally averaged (a) source resolved mass concentration and (b) O:C profiles for the two-bin volatility shift scenario. Observations (bullets) appear with error bars indicating measurement uncertainty.

aging is the principal driving force for $\mathrm{O}: \mathrm{C}$ increases in the ambient, then significant material must exist at exceptionally high O:C (>0.9) in order to overcome the comparably small $\mathrm{O}: \mathrm{C}$ increase from mass that condenses to the particle phase at $\mathrm{O}: \mathrm{C}$ of 0.4 to 0.6 .

High oxygen addition. When the aging mechanism adds 3 or 4 oxygen atoms with a 1-decade reduction in effective saturation concentration, the average OA mass and volatility change little from the base case $\left(\mathrm{C}_{\mathrm{OA}}=3.4 \mu \mathrm{g} \mathrm{m}^{-3}\right.$ and $C^{*}=0.66 \mu \mathrm{g} \mathrm{m}^{-3}$ ). On the other hand, the average O:C increases significantly to 0.94 . There is also enhanced build-up of mass at the highest O:C. This O:C increase is not supported by the AMS measurements, falling well above the upper limit of the uncertainty in the measurement.

Low oxygen addition. This case results in a decrease in the average $\mathrm{C}_{\mathrm{OA}}\left(2.9 \mu \mathrm{g} \mathrm{m}^{-3}\right)$, a considerable decrease in average volatility $\left(C^{*}=0.18 \mu \mathrm{g} \mathrm{m}^{-3}\right)$, and a sizable decrease in oxygenation $(\mathrm{O}: \mathrm{C}=0.51)$. The decrease in mass is associated with reducing the mass added by oxygen throughout the simulation. The underprediction for average organic mass and average $\mathrm{O}: \mathrm{C}$ are not supported by the observations of either metric, and this aging scenario is likely not a realistic depiction of organic compound aging in the atmosphere.

Biogenic SOA. Two simulations were performed to investigate the effects of adding bSOA aging. The first case treats bSOA with the same reaction rate constant as aSOA and ages it with the 1-bin shift formulation. This approach results in overprediction (Fig. 9) of the FAME-08 OA mass concentration measurements, and similar average performance in predicting $\mathrm{O}: \mathrm{C}$ as the base case. In the second case, reducing the aging rate constant for all OA constituents by a factor of 4 results in slight underprediction of the OA concentration and underprediction of O:C. Taken together, these results suggest
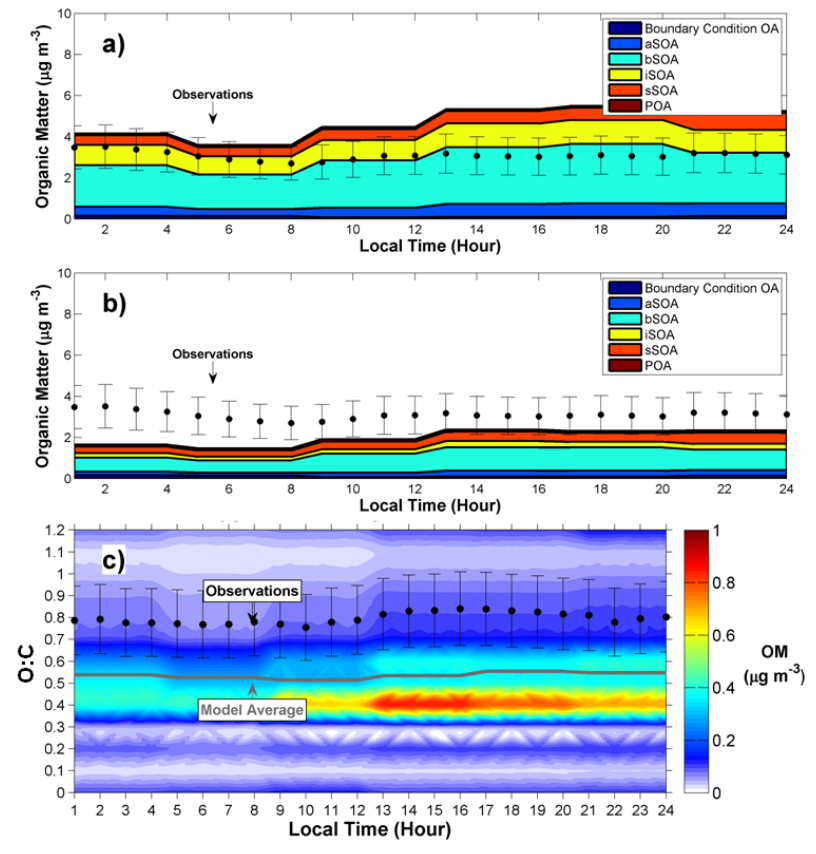

Fig. 9. Diurnally averaged (a,b) OA mass concentrations for the cases with bSOA aging with $\mathrm{OH}$ reaction rate constant of $1 \times 10^{-11}$ and $0.25 \times 10^{-11} \mathrm{~cm}^{3} \mathrm{molec}^{-1} \mathrm{~s}^{-1}$, respectively. (c) $\mathrm{O}: \mathrm{C}$ for the low $\mathrm{OH}$ aging rate constant case.

that it may not be appropriate to treat aSOA and bSOA aging in the same way, at least from the perspective of this simple implementation of the 2D-VBS, which only considers functionalization of organic molecules. This does not mean that bSOA aging can be ignored. Fragmentation processes are likely important in reducing the mass produced by aging and thus bringing this system back into agreement with the measurements. These processes are not simulated in this work. More chamber studies and modeling efforts of both aSOA and bSOA systems at long oxidation timescales are needed to characterize this behavior.

\subsubsection{Heterogeneous oxidative aging}

The heterogeneous oxidative aging sensitivity study did not result in significant change to the OA mass concentrations or degree of oxygenation compared to the base-case predictions. The small scale of this enhancement is likely due to the slow reaction rate assumed for this process. The rate was chosen to be consistent with available observations of $\mathrm{OH}$ uptake rates to organic particles so it is not expected that this estimate is far from reality. However, this is only one of a few pathways for organic compound oxidation involving more than one phase. These other pathways, including aqueous phase processing, could be responsible for some $\mathrm{O}: \mathrm{C}$ enhancements as well. There is a decrease in volatility $\left(C^{*}=0.4 \mu \mathrm{g} \mathrm{m}^{-3}\right)$ due to continued reaction of OA mass with gas-phase $\mathrm{OH}$. The further volatility reduction is comparable 
to, although a little smaller than, the uncertainty in choosing between the 1- and 2-decade volatility shift approaches. This is consistent with the trends seen by Hildebrandt et al. (2010) during the FAME-08 campaign. That study reported similar levels of oxygenation for parcels they believed to originate from the same source location but vary in the time they took to arrive at Finokalia. Future implementations of this model will investigate other heterogeneous-phase mechanisms of $\mathrm{OA}$ formation and their effects on the predictions of $\mathrm{O}: \mathrm{C}$ and volatility.

\section{Implications}

A proof of concept model for predicting OA formation with the $2 \mathrm{D}$ volatility basis set in a Lagrangian chemical transport host model has been presented and its results have been evaluated with extensive measurements from the Finokalia Aerosol Measurement Experiment campaign. The base-case model, performs encouragingly well for predicting OA mass concentrations, average volatility, and average $\mathrm{O}: \mathrm{C}$ for a representative day (diurnal average of 9 days) in May 2008. While this performance is encouraging, it is important to emphasize some factors that limit the strength of conclusions that could be drawn from this study. This work only involves data obtained from one site during the EUCAARI measurement campaign. Other sites and time periods will be analyzed in the future to explore the reproducibility of these results. Further, the data obtained from the FAME site are rather constant, and the model is not tested for its ability to reproduce extensive variability in the system. When other sites with more local sources are chosen, these aspects of the model's performance will be emphasized to a much larger extent. Lastly, because of the large number of uncertain parameters available in this model, some of them (number of oxygen atoms added, number of volatility bins shifted) were chosen beforehand (within reasonable limits) with the goal of achieving highly oxygenated OA at Finokalia. However, other uncertain parameters like the $\mathrm{OH}$ aging reaction rate constant, water solubility of organic gases, enthalpy of vaporization, etc were input directly from previous studies. The base-case model configuration used in this study should not be viewed as the "correct" answer for an OA aging model. It is only one of many possible configurations that will achieve good performance as quantified by the metrics we have chosen to address here.

The model was used to explore the reasonableness of alternative aging scenarios like the 2-bin (or decade) reduction in volatility. Constraining the aging mechanism with the measurement of O:C successfully eliminated some possible scenarios (such as the 2-bin volatility shift with reduced aging rate constant, the high oxygen addition, the low oxygen addition, and the bSOA aging cases) because they produced OA that was too oxygenated or too hydrocarbon-like compared to the observations. However, including fragmentation processes, which may lead to decreased mass at higher O:C could have an effect on the predictions here. The inclusion of bSOA in aging mechanisms was also explored and although aging parameters could be adjusted to bring mass concentrations into agreement with observations, these changes resulted in unrealistically low O:C predictions. Additional laboratory studies of this complex aging process are required to allow its simulation in CTMs. Specifically, knowing how important fragmentation processes are, and what factors drive them would be a considerable step forward in modeling this system. On a related point, because of the high concentrations of hydroxyl radicals used in smog chamber experiments, it is entirely possible that the yields used in this work for aSOA and bSOA formation include some mass formed from aging processes and not just yields of first-generation products. It will be important in the future to distinguish these two categories from each other for both aSOA and bSOA formation. This will help address the rather unintuitive assumption that aSOA compounds age while those from bSOA do not.

Other assumptions required by the 2D-VBS framework were explored in this study including the initial O:C distribution for first-generation SOA compounds and the presence of heterogeneous oxidation. Including a variable O:C distribution for SOA compounds when they enter the 2D-VBS, as opposed to assuming a constant value of 0.4 regardless of volatility, resulted in a 10-15\% decrease in average O:C throughout the representative simulation day. Including heterogeneous reaction of condensed phase organic compounds with $\mathrm{OH}$ did very little to alter the volatility or O:C distribution from that of the base case. However, other heterogeneous processes like SOA production from glyoxal, or accretion reactions may still be important. This model will be used in the future to further evaluate and constrain the 2D-VBS with measurement campaign data from locations throughout the world. It can also be used to investigate uncertain features of organic aerosol behavior like mixing interactions and fog processing. Generally, this model represents a substantial step forward in the ability to synthesize constraints from experimental studies and ambient measurements to inform our conceptual picture of atmospheric organic aerosol formation.

Acknowledgements. This research was supported by the Electric Power Research Institute (EPRI) and the European Research Council (project ATMOPACS).

Edited by: M. Kanakidou

\section{References}

Aiken, A. C., Decarlo, P. F., Kroll, J. H., Worsnop, D. R., Huffman, J. A., Docherty, K. S., Ulbrich, I. M., Mohr, C., Kimmel, J. R., Sueper, D., Sun, Y., Zhang, Q., Trimborn, A., Northway, M., Ziemann, P. J., Canagaratna, M. R., Onasch, T. B., Alfarra, 
M. R., Prevot, A. S. H., Dommen, J., Duplissy, J., Metzger, A., Baltensperger, U., and Jimenez, J. L.: O/C and OM/OC ratios of primary, secondary, and ambient organic aerosols with high-resolution time-of-flight aerosol mass spectrometry, Environ. Sci. Technol., 42, 4478-4485, doi:10.1021/Es703009q, 2008.

Atkinson, R.: Atmospheric Chemistry of VOCs and NOx, Atmos. Environ., 34, 2063-2101, 2000.

Bertram, A. K., Ivanov, A. V., Hunter, M., Molina, L., and Molina, M. J.: The reaction probability of $\mathrm{OH}$ on organic surfaces of tropospheric interest, J. Chem. Phys.-US, 105, 9415-9421, doi:10.1021/jp0114034, 2001.

Binkowski, F. and Roselle, S. J.: Models-3 Community Multiscale Air Quality (CMAQ) model aerosol component 1. model description, J. Geophys. Res., 108, 4183, doi:10.1029/2001JD001409, 2003.

Cappa, C. D. and Jimenez, J. L.: Quantitative estimates of the volatility of ambient organic aerosol, Atmos. Chem. Phys., 10, 5409-5424, doi:10.5194/acp-10-5409-2010, 2010.

Chan, A. W. H., Kautzman, K. E., Chhabra, P. S., Surratt, J. D., Chan, M. N., Crounse, J. D., Krten, A., Wennberg, P. O., Flagan, R. C., and Seinfeld, J. H.: Secondary organic aerosol formation from photooxidation of naphthalene and alkylnaphthalenes: implications for oxidation of intermediate volatility organic compounds (IVOCs), Atmos. Chem. Phys., 9, 3049-3060, doi:10.5194/acp-9-3049-2009, 2009.

Chow, J. C., Watson, J. G., Crow, D., Lowenthal, D. H., and Merrifield, T.: Comparison of IMPROVE and NIOSH carbon measurements, Aerosol Sci. Tech., 34, 23-34, 2001.

Donahue, N. M., Robinson, A. L., Stanier, C. O., and Pandis, S. N.: Coupled partitioning, dilution, and chemical aging of semivolatile organics, Environ. Sci. Technol., 40, 2635-2643, doi:10.1021/es052297c, 2006.

Donahue, N. M., Epstein, S. A., Pandis, S. N., and Robinson, A. L.: A two-dimensional volatility basis set: 1. organic-aerosol mixing thermodynamics, Atmos. Chem. Phys., 11, 3303-3318, doi:10.5194/acp-11-3303-2011, 2011.

Draxler, R., Stunder, B., Rolph, G., Stein, A., and Taylor, A.: HYSPLIT4 User's Guide, NOAA, Silver Spring, MD, 231, 2009.

Dzepina, K., Volkamer, R. M., Madronich, S., Tulet, P., Ulbrich, I. M., Zhang, Q., Cappa, C. D., Ziemann, P. J., and Jimenez, J. L.: Evaluation of recently-proposed secondary organic aerosol models for a case study in Mexico City, Atmos. Chem. Phys., 9, 5681-5709, doi:10.5194/acp-9-5681-2009, 2009.

Epstein, S. A., Riipinen, I., and Donahue, N. M.: A semiempirical correlation between enthalpy of vaporization and saturation concentration for organic aerosol, Environ. Sci. Technol., 44, 743748, doi:10.1021/Es902497z, 2010.

Farina, S. C., Adams, P. J., and Pandis, S. N.: Modeling global secondary organic aerosol formation and processing with the volatility basis set: Implications for anthropogenic secondary organic aerosol, J. Geophys. Res., 115, D09202, doi:10.1029/2009JD013046, 2010.

Fuzzi, S., Andreae, M. O., Huebert, B. J., Kulmala, M., Bond, T. C., Boy, M., Doherty, S. J., Guenther, A., Kanakidou, M., Kawamura, K., Kerminen, V.-M., Lohmann, U., Russel, L. M., and Pöschl, U.: Critical assessment of the current state of scientific knowledge, terminology, and research needs concerning the role of organic aerosols in the atmosphere, climate, and global change, Atmos. Chem. Phys., 6, 2017-2038, doi:10.5194/acp-62017-2006, 2006.

Gaydos, T. M., Koo, B., Pandis, S. N., and Chock, D. P.: Development and application of an efficient moving sectional approach for the solution of the atmospheric aerosol condensation/evaporation equations, Atmos. Environ., 37, 3303-3316, doi:10.1016/S1352-2310(03)00267-X, 2003.

Gaydos, T. M., Pinder, R., Koo, B., Fahey, K. M., Yarwood, G., and Pandis, S. N.: Development and application of a three-dimensional aerosol chemical transport model, PMCAMx, Atmos. Environ., 41, 2594-2611, doi:10.1016/j.atmosenv.2006.11.034, 2007.

Geever, M., O’Dowd, C. D., Ekeren, S., Flanagan, R., Nilsson, E. D., Leeuw, G., and Rannik, U.: Submicron sea spray fluxes, Geophys. Res. Lett., 32, L15810, doi:10.1029/2005GL023081, 2005.

George, I. J., Vlasenko, A., Slowik, J., Broekhuizen, K., and Abbatt, J. P. D.: Heterogeneous oxidation of saturated organic aerosols by hydroxyl radicals: upatake kinetics, condesned-phase products, and particle size change, Atmos. Chem. Phys., 7, 41874201, doi:10.5194/acp-7-4187-2007, 2007.

George, I. J., Slowik, J., and Abbatt, J. P. D.: Chemical aging of ambient organic aerosol from heterogeneous reaction with hydroxyl radicals, Geophys. Res. Lett., 35, L13811, doi:10.1029/2008g1033884, 2008.

George, I. J. and Abbatt, J. P. D.: Chemical evolution of secondary organic aerosol from $\mathrm{OH}$-initiated heterogeneous oxidation, Atmos. Chem. Phys., 10, 5551-5563, doi:10.5194/acp-10-55512010, 2010.

Goldstein, A. H. and Galbally, I. E.: Known and unexplored organic constituents in the Earth's atmosphere, Environ. Sci. Technol., 41, 1514-1521, doi:10.1021/es072476p, 2007.

Grieshop, A. P., Donahue, N. M., and Robinson, A. L.: Is the gas-particle partitioning in alpha-pinene secondary organic aerosol reversible?, Geophys. Res. Lett., 34, L14810, doi:10.1029/2007g1029987, 2007.

Grieshop, A. P., Logue, J. M., Donahue, N. M., and Robinson, A. L.: Laboratory investigation of photochemical oxidation of organic aerosol from wood fires 1: measurement and simulation of organic aerosol evolution, Atmos. Chem. Phys., 9, 1263-1277, doi:10.5194/acp-9-1263-2009, 2009.

Griffin, R. J., Cocker III, D. R., Flagan, R. C., and Seinfeld, J. H.: Organic aerosol formation from the oxidation of biogenic hydrocarbons, J. Geophys. Res., 104, 3555-3567, 1999.

Griffin, R. J., Dabdub, D., and Seinfeld, J. H.: Development and initial evaluation of a dynamic species-resolved model for gas phase chemistry and size-resolved gas/particle partitioning associated with secondary organic aerosol formation, J. Geophys. Res.-Atmos., 110, D05304, doi:10.1029/2004jd005219, 2005.

Guenther, A., Karl, T., Harley, P., Wiedinmyer, C., Palmer, P. I., and Geron, C.: Estimates of global terrestrial isoprene emissions using MEGAN (Model of Emissions of Gases and Aerosols from Nature), Atmos. Chem. Phys., 6, 3181-3210, doi:10.5194/acp-63181-2006, 2006.

Heald, C. L., Jacob, D. J., Park, R. J., Russel, L. M., Huebert, B. J., Seinfeld, J. H., Liao, H., and Weber, R. J.: A large organic aerosol source in the free troposphere missing from current models, Geophys. Res. Lett., 32, 18809, doi:10.1029/2005GL023831, 2005.

Heald, C. L., Kroll, J. H., Jimenez, J. L., Docherty, K. S., DeCarlo, 
P. F., Aiken, A. C., Chen, Q., Martin, S. T., Farmer, D. K., and Artaxo, P.: A simplified description of the evolution of organic aerosol composition in the atmosphere, Geophys. Res. Lett., 37, L08803, doi:10.1029/2010g1042737, 2010.

Hildebrandt, L., Donahue, N. M., and Pandis, S. N.: High formation of secondary organic aerosol from the photo-oxidation of toluene, Atmos. Chem. Phys., 9, 2973-2986, doi:10.5194/acp-92973-2009, 2009.

Hildebrandt, L., Engelhart, G. J., Mohr, C., Kostenidou, E., Lanz, V. A., Bougiatioti, A., DeCarlo, P. F., Prevot, A. S. H., Baltensperger, U., Mihalopoulos, N., Donahue, N. M., and Pandis, S. N.: Aged organic aerosol in the Eastern Mediterranean: the Finokalia Aerosol Measurment Experiment - 2008, Atmos. Chem. Phys., 10, 4167-4186, doi:10.5194/acp-10-4167-2010, 2010.

Hodzic, A., Jimenez, J. L., Madronich, S., Canagaratna, M. R., DeCarlo, P. F., Kleinman, L., and Fast, J.: Modeling organic aerosols in a megacity: potential contribution of semi-volatile and intermediate volatility primary organic compounds to secondary organic aerosol formation, Atmos. Chem. Phys., 10, 5491-5514, doi:10.5194/acp-10-5491-2010, 2010.

Huffman, J. A., Docherty, K., Aiken, A. C., Cubison, M. J., Ulbrich, I., DeCarlo, P. F., Sueper, D., Jayne, J. T., Worsnop, D. R., Ziemann, P. J., and Jimenez, J. L.: Chemically-resolved aerosol volatility measurements from two megacity field studies, Atmos. Chem. Phys., 9, 7161-7182, doi:10.5194/acp-9-7161-2009, 2009.

Jimenez, J. L., Canagaratna, M. R., Donahue, N. M., Prevot, A. S. H., Zhang, Q., Kroll, J. H., DeCarlo, P. F., Allan, J. D., Coe, H., Ng, N. L., Aiken, A. C., Docherty, K., Ulbrich, I., Grieshop, A. P., Robinson, A. L., Duplissy, J., Smith, J. D., Wilson, K. R., Lanz, V. A., Hueglin, C., Sun, Y. L., Tian, J., Laaksonen, A., Raatikainen, T., Rautiainen, J., Vaattovaara, P., Ehn, M., Kulmala, M., Tomlinson, J. M., Collins, D. R., Cubison, M. J., Dunlea, E., Huffman, J. A., Onasch, T. B., Alfarra, M. R., Williams, P., Bower, K., Kondo, Y., Schneider, J., Drewnick, F., Borrmann, S., Weimer, S., Demerjian, K., Salcedo, D., Cottrell, L., Griffin, R. J., Takami, A., Miyoshi, T., Hatakeyama, S., Shimono, A., Sun, J. Y., Zhang, Y. M., Dzepina, K., Kimmel, J. R., Sueper, D., Jayne, J. T., Herndon, S. C., Trimborn, A., Williams, L. R., Wood, E. C., Middlebrook, A. M., Kolb, C. E., Baltensperger, U., and Worsnop, D. R.: Evolution of organic aerosols in the atmosphere, Science, 326, 1525-1529, 2009.

Kanakidou, M., Seinfeld, J. H., Pandis, S. N., Barnes, I., Dentener, F. J., Facchini, M. C., Dingenen, R. V., Ervens, B., Nenes, A., Nielsen, C. J., Swietlicki, E., Putaud, J. P., Balkanski, Y., Fuzzi, S., Horth, J., Moortgat, G. K., Winterhalter, R., Myhre, C. E. L., Tsigaridis, K., Vignati, E., Stephanou, E. G., and Wilson, J.: Organic aerosol and global climate modeling: a review, Atmos. Chem. Phys., 5, 1053-1123, doi:0.5194/acp-5-1053-2005, 2005.

Koo, B. Y., Ansari, A. S., and Pandis, S. N.: Integrated approaches to modeling the organic and inorganic atmospheric aerosol components, Atmos. Environ., 37, 4757-4768, doi:10.1016/j.atmosenv.2003.08.016, 2003.

Kostenidou, E., Lee, B.-H., Engelhart, G. J., Pierce, J. R., and Pandis, S. N.: Mass spectra deconvolution of low, medium, and high volatility biogenic secondary organic aerosol, Environ. Sci. Technol., 43, 4884-4889, 2009.

Kroll, J. H., Smith, J. D., Che, D. L., Kessler, S. H., Worsnop, D. R., and Wilson, K. R.: Measurement of fragmentation and func- tionalization pathways in the heterogeneous oxidation of oxidized organic aerosol, Phys. Chem. Chem. Phys., 11, 8005-8014, doi:10.1039/B905289e, 2009.

Kroll, J. H., Donahue, N. M., Jimenez, J., Kessler, S. H., Canagaratna, M., Wilson, K. R., Altieri, K., Mazzoleni, L. R., Wozniak, A. S., Bluhm, H., Mysak, E. R., Smith, J. D., Kolb, C. E., and Worsnop, D. R.: Carbon oxidation state as a metric for describing the chemistry of atmospheric organic aerosol, Nature Chemistry, 3, 133-139, doi:10.1038/nchem.948, 2011.

Kulmala, M., Asmil, A., Lappalainen, H. K., Carslaw, K. S., Poschl, U., Baltensperger, U., Hoy, O., Brenquier, J.-L., Pandis, S. N., Facchini, M. C., Hansson, H. C., Wiedensohler, A., and O'Dowd, C. D.: Introduction: European Integrated Project on Aerosol Cloud Climate and Air Quality interactions (EUCAARI) - integrating aerosol research from nano to global scales, Atmos. Chem. Phys., 9, 2825-2841, dio:10.5194/acp-9-2825-2009, 2009.

Lambe, A. T., Zhang, J., Sage, A. M., and Donahue, N. M.: Controlled $\mathrm{OH}$ radical production via ozone-alkene reactions for use in aerosol aging studies, Environ. Sci. Technol., 41, 2357-2363, 2007.

Lane, T. E., Donahue, N. M., and Pandis, S. N.: Simulating secondary organic aerosol formation using the volatility basis-set approach in a chemical transport model, Atmos. Environ., 42, 7439-7451, 2008.

Lee, B.-H., Kostenidou, E., Hildebrandt, L., Riipinen, I., Engelhart, G. J., Mohr, C., DeCarlo, P. F., Mihalopoulos, N., Prevot, A. S. H., Baltensperger, U., and Pandis, S. N.: Measurement of the ambient organic aerosol volatility distribution: application during the Finokalia Aerosol Measurement Experiment (FAME2008), Atmos. Chem. Phys., 10, 12149-12160, doi:10.5194/acp10-12149-2010, 2010.

Lipsky, E. M. and Robinson, A. L.: Effects of dilution on fine particle mass and partitioning of semivolatile organics in diesel exhaust and wood smoke, Environ. Sci. Technol., 40, 155-162, 2006.

Morgan, W. T., Allan, J. D., Bower, K. N., Highwood, E. J., Liu, D., McMeeking, G. R., Northway, M. J., Williams, P. I., Krejci, R., and Coe, H.: Airborne measurements of the spatial distribution of aerosol chemical composition across Europe and evolution of the organic fraction, Atmos. Chem. Phys., 10, 4065-4083, doi:10.5194/acp-10-4065-2010, 2010.

Morris, R. E., Koo, B., Guenther, A., Yarwood, G., McNally, D., Tesche, T. W., Tonnesen, G., Boylan, J., and Brewer, P.: Model sensitivity evaluation for organic carbon using two multipollutant air quality models that simulate regional haze in the southeastern United States, Atmos. Environ., 40, 4960-4972, 2006.

Murphy, B. N. and Pandis, S. N.: Simulating the formation of semivolatile primary and secondary organic aerosol in a regional chemical transport model, Environ. Sci. Technol., 43, 47224728, 2009.

Murphy, B. N. and Pandis, S. N.: Exploring summertime organic aerosol formation in the eastern United States using a regionalscale budget approach and ambient measurements, J. Geophys. Res., 115(12), D24216, doi:10.1029/2010JD014418, 2010.

Ng, N. L., Canagaratna, M. R., Zhang, Q., Jimenez, J. L., Tian, J., Ulbrich, I., Kroll, J. H., Docherty, K., Chhabra, P. S., Bahreini, R., Murphy, S. M., Seinfeld, J. H., Hildebrandt, L., DeCarlo, 
P. F., Lanz, V. A., Prevot, A. S. H., Dinar, E., Rudlich, Y., and Worsnop, D. R.: Organic aerosol components observed in Northern Hemispheric datasets from aerosol mass spectrometry, Atmos. Chem. Phys., 10, 4625-4641, doi:10.5194/acp-10-46252010, 2010.

O’Dowd, C. D., Langmann, B., Varghese, S., Scannell, C., Ceburnis, D., and Facchini, M. C.: A combined organic-inorganic sea spray source function, Geophys. Res. Lett., 35, L01801, doi:10.1029/2007GL030331, 2008.

Odum, J. R., Hoffman, T., Bowman, F., Collins, D., Flagan, R. C., and Seinfeld, J. H.: Gas/particle partitioning and secondary organic aerosol yields, Environ. Sci. Technol., 30, 2580-2585, 1996.

Pandis, S. N., Harley, R. A., Cass, G. R., and Seinfeld, J. H.: Secondary organic aerosol formation and transport, Atmos. Environ. A-Gen., 26, 2269-2282, 1992.

Pankow, J. F.: An absorption model of the gas/aerosol partitioning involved in the formation of secondary organic aerosol, Atmos. Environ., 28, 185-188, 1994.

Pankow, J. F. and Asher, W. E.: SIMPOL.1: a simple group contribution method for predicting vapor pressures and enthalpies of vaporization of multifunctional organic compounds, Atmos. Chem. Phys., 8, 2773-2796, doi:10.5194/acp-8-27732008, 2008.

Pathak, R. K., Presto, A. A., Lane, T. E., Stanier, C. O., Donahue, N. M., and Pandis, S. N.: Ozonolysis of alpha-pinene: parameterization of secondary organic aerosol mass fraction, Atmos. Chem. Phys., 7, 3811-3821, doi:10.5194/acp-7-3811-2007, 2007.

Pikridas, M., Bougiatioti, A., Hildebrandt, L., Engelhart, G. J., Kostenidou, E., Mohr, C., Prevot, A. S. H., Kouvarakis, G., Zarmpas, P., Burkhart, J. F., Lee, B.-H., Psichoudaki, M., Mihalopoulos, N., Pilinis, C., Stohl, A., Baltensperger, U., Kulmala, M., and Pandis, S. N.: The Finokalia Aerosol Measurement Experiment - 2008 (FAME-08): an overview, Atmos. Chem. Phys., 10, 6793-6806, doi:10.5194/acp-10-6793-2010, 2010.

Presto, A. A. and Donahue, N. M.: Investigation of alphapinene + ozone secondary organic aerosol formation at low total aerosol mass, Environ. Sci. Technol., 40, 3536-3543, 2006.

Qi, L., Nakao, S., Malloy, Q., Warren, B., and Cocker, D. R. I.: Can secondary organic aerosol formed in an atmospheric simulation chamber continuously age?, Atmos. Environ., 44, 2990-2996, 2010.

Riipinen, I., Pierce, J. R., Donahue, N. M., and Pandis, S. N.: Equilibration time scales of organic aerosol inside thermodenuders: evaporation kinetics versus thermodynamics, Atmos. Environ., 44, 597-607, doi:10.1016/j.atmosenv.2009.11.022, 2010.

Robinson, A. L., Donahue, N. M., Shrivastava, M. K., Weitkamp, E. A., Sage, A. M., Grieshop, A. P., Lane, T. E., Pierce, J. R., and Pandis, S. N.: Rethinking organic aerosol: semivolatile emissions and photochemical aging, Science, 315, 1259-1262, 2007.

Seinfeld, J. H. and Pandis, S. N.: Atmospheric Chemistry and Physics: From Air Pollution to Climate Change, 2nd ed., John Wiley and Sons, Hoboken, New Jersey, USA, 2006.

Shilling, J. E., Chen, Q., King, S. M., Rosenoern, T., Kroll, J. H., Worsnop, D. R., DeCarlo, P. F., Aiken, A. C., Sueper, D., Jimenez, J. L., and Martin, S. T.: Loading-dependent elemental composition of $\alpha$-pinene SOA particles, Atmos. Chem. Phys., 9, 771-782, doi:10.5194/acp-9-771-2009, 2009.

Shrivastava, M. K., Lipsky, E. M., Stanier, C. O., and Robinson,
A. L.: Modeling semivolatile organic aerosol mass emissions from combustion systems, Environ. Sci. Technol., 40, 26712677, 2006.

Shrivastava, M. K., Lane, T. E., Donahue, N. M., Pandis, S. N., and Robinson, A. L.: Effects of gas-particle partitioning and aging of primary emissions on urban and regional organic aerosol Concentrations, J. Geophys. Res., 113, D18301, doi:10.1029/2007JD009735, 2008.

Skamarock, W. C., Klemp, J. B., Dudhia, J., Gill, D. O., Duda, M. G., Huang, X., Wang, W., and Powers, J. G.: A Description of the Advanced Research WRF Version 3, National Center for Atmspheric Research (NCAR), Boulder, CONCAR/TN475+STR, 2008.

Sofiev, M., Lanne, M., Vankevich, R., Prank, M., Karppinen, A., and Kukkonen, J.: Impact of wild-land fires on European air quality in 2006-2008, Modeling, Monitoring and Management of Forest Fires, Wit. Trans. Ecol. Envir., 119, 353-361, 2008a.

Sofiev, M., Vankevich, R., Lanne, M., Koskinen, J., and Kukkonen, J.: On integration of a Fire Assimilation System and a chemical transport model for near-real-time monitoring of the impact of wild-land fires on atmospheric composition and air quality, Modeling, Monitoring and Management of Forest Fires, Wit. Trans. Ecol. Envir., 119, 343-351, 2008b.

Stanier, C. O., Donahue, N., and Pandis, S. N.: Parameterization of secondary organic aerosol mass fractions from smog chamber data, Atmos. Environ., 42, 2276-2299, 2008.

Strader, R., Lurmann, F., and Pandis, S. N.: Evaluation of secondary organic aerosol formation in winter, Atmos. Environ., 33, 48494863, 1999.

Tsimpidi, A. P., Karydis, V. A., Zavala, M., Lei, W., Molina, L., Ulbrich, I. M., Jimenez, J. L., and Pandis, S. N.: Evaluation of the volatility basis-set approach for the simulation of organic aerosol formation in the Mexico City metropolitan area, Atmos. Chem. Phys., 10, 525-546, doi:10.5194/acp-10-525-2010, 2010.

Visschedijk, A. J., Zandveld, P., and Denier van der Gon, H. A. C.: TNO Report 2007 A-R0233/B: A high resolution gridded European emission database for the EU integrated project GEMS, Organization for Applied Scientific Research, The Netherlands, 2007.

Watson, J. G., Chow, J., and Chen, L.-W. A.: Summary of organic and elemental carbon/black carbon analysis methods and intercomparisons, Aerosol. Air Qual. Res., 5, 65-102, 2005.

Weitkamp, E. A., Lambe, A. T., Donahue, N. M., and Robinson, A. L.: Laboratory measurements of the heterogeneous oxidation of condensed-phase organic molecular makers for motor vehicle exhaust, Environ. Sci. Technol., 42, 7950-7956, doi:10.1021/es800745x, 2008.

Zhang, Q., Jimenez, J. L., Canagaratna, M. R., Allan, J. D., Coe, H., Ulbrich, I., Alfarra, M. R., Takami, A., Middlebrook, A. M., Sun, Y. L., Dzepina, K., Dunlea, E., Docherty, K., DeCarlo, P. F., Salcedo, D., Onasch, T., Jayne, J. T., Miyoshi, T., Shimono, A., Hatakeyama, S., Takegawa, N., Kondo, Y., Schneider, J., Drewnick, F., Borrmann, S., Weimer, S., Demerjian, K., Williams, P., Bower, K., Bahreini, R., Cottrell, L., Griffin, R. J., Rautiainen, J., Sun, J. Y., Zhang, Y. M., and Worsnop, R.: Ubiquity and dominance of oxygenated species in organic aerosols in anthropogenically-influenced Northern Hemisphere midlatitudes, Geophys. Res. Lett., 34, L1380113806, doi:10.1029/2007GL029979, 2007. 